\title{
The Influence Aim Problem of Petitionary Prayer: A Cosmic Conflict Approach
}

\author{
John C. Peckham \\ Andrews University
}

\begin{abstract}
This article addresses the problem of whether petitionary prayer, specifically of the kind aimed at influencing God to bring about some good he otherwise would not have brought about, is consistent with the traditional Christian affirmations of divine omniscience, omnipotence, and omnibenevolence. In this article, I first briefly articulate the influence aim problem of petitionary prayer, then briefly introduce and discuss some common approaches to resolving the problem. Finally, I introduce and discuss some implications of retrieving a cosmic conflict approach with rules of engagement as a possible avenue that warrants further consideration relative to the influence aim problem of petitionary prayer.
\end{abstract}

Does it make sense to offer petitionary prayer to God with the expectation that such prayer might influence God to bring about some good he otherwise would not have brought about? Many Christians frequently petition God to mitigate perceived evils and bring about desired goods and do so with the belief that such petitions might make a difference relative to divine action. As Scott A. Davison puts it, "one of the primary purposes of petitionary prayer, according to those who practice it, is to influence God's action in the world" $(2017,7) .{ }^{1}$

However, numerous philosophers and theologians have questioned whether petitionary prayer is coherent with the basic tenets of Christian theism, particularly divine omniscience, omnipotence, and omnibenevolence (see, e.g., Stump 1979, 81; Basinger 1983, 25-26). This article seeks to advance the discussion regarding the problem of whether petitionary prayer aimed at influencing divine action is consistent with divine omniscience, omnipotence, and omnibenevolence. I will first briefly articulate the influence aim problem of petitionary prayer. Then, I will briefly introduce and discuss some common approaches that might apply to this problem. Finally, I will suggest a rules-of-engagement approach to the influence aim problem of petitionary prayer, based on a retrieval of the traditional (but oft-neglected) motif of cosmic conflict.

${ }^{1}$ While offering a more nuanced account of prayer than many Christians may have in mind when they pray, Karl Barth captures what many Christians believe when he writes, "God answers. God is not deaf, but listens; more than that, he acts. God does not act in the same way whether we pray or not. Prayer exerts an influence upon God's action" $(2002,13)$.

Journal of Analytic Theology, Vol. 8, August 2020

10.12978/jat.2020-8.0914021504-65

(C) 2020 John C. Peckham • (C) 2020 Journal of Analytic Theology 


\section{The Influence Aim Problem of Petitionary Prayer}

As I define it, the influence aim problem of petitionary prayer (IAP) is the problem of whether one can consistently affirm that petitionary prayer might influence God to bring about some good he otherwise would not have brought about, while also affirming that God is omniscient, omnibenevolent, and omnipotent. ${ }^{2}$ It seems that an omniscient, omnibenevolent, and omnipotent God would know all preferable goods he could bring about, would prefer to bring about such goods, and would be capable of doing so. ${ }^{3}$ How, then, could it make sense to believe that petitionary prayer might influence God to bring about some good he otherwise would not bring about? ${ }^{4}$

This influence aim problem of petitionary prayer may be articulated in terms of the following four premises:

(1) God is omniscient.

(2) God is omnibenevolent.

(3) God is omnipotent.

(4) Petitionary prayer might influence God to bring about some good he otherwise would not have brought about. ${ }^{5}$

For the remainder of this article, I will refer to (4) as the influence aim. ${ }^{6}$ The influence aim problem of petitionary prayer (IAP) relates to the view of many thinkers that to consistently affirm (4) would require one to deny one or more of (1)(3). That is, it seems that affirming the influence aim of petitionary prayer requires either that God is somehow: (a) informed by the prayer, contra omniscience, (b) influenced to prefer some good he otherwise would not, contra omnibenevolence, or (c) increased in power, contra omnipotence.

Many treatments note that petitionary prayer might have some positive effect(s) apart from influencing God. ${ }^{7}$ Accordingly, the problem at hand is not whether petitionary prayer can be thought of in some way that is coherent with divine omniscience, omnibenevolence, and omnipotence, but more specifically whether it is coherent to affirm that petitionary prayer might influence God to act otherwise than

\footnotetext{
${ }^{2}$ While there are many other problems related to petitionary prayer (see Cocksworth 2018,139-168), in this brief essay I leave these aside and focus on the IAP.

${ }^{3}$ I deliberately refer to preferable goods rather than best possible goods given that there may not be a best possible world or even a best possible good in a given situation. See Adams, 1972; cf. Reibsamen 2019, 136-37.

${ }^{4}$ Davison writes: "If I pray for something good to happen, then God already has a reason to bring it about, whether or not I pray for it, since it is a good thing" $(2009,290)$.

${ }^{5}$ Here and elsewhere, I intentionally leave open whether such petitionary prayer is offered by only one person or a group.

${ }^{6}$ In this article, I use the term "influence" in the sense of somehow counterfactually affecting what God brings about, which need not include any influence on what God ideally desires.

${ }^{7}$ For instance, Davison notes, petitionary prayer "changes the person who prays, unites people in a common cause, and communicates important values to others, to name just a few examples" $(2017,7)$.
} 
he would have. In this regard, many treatments assume that petitionary prayer is efficacious only if it influences God to bring about something he otherwise would not have (so-called counterfactual dependence accounts). However, some philosophers have persuasively argued that petitionary prayer might be efficacious even if God would have actualized the prayed-for outcome apart from the influence of petitionary prayer, so long as "God brings about the thing in question at least in part because the person prays for it" (Davison 2009, 288; cf. Davison 2017, 26-42; Cohoe 2014, 3739).

I believe Davison and Cohoe make convincing cases that, as Cohoe puts it, the "efficacy of petitionary prayers does not require counterfactual dependence" (Cohoe $2014,38) .{ }^{8}$ However, as Cohoe notes, "many important cases of petitionary prayer do involve counterfactual dependence" (Cohoe 2014, 38). Rather than seeking to address the ongoing discussion regarding what counts as efficacious prayer, as important as it is, this article focuses on advancing the discussion regarding cases that involve counterfactual dependence, especially relative to petitionary prayers aimed at counterfactually influencing God to prevent some great evil or provide some basic need.

In this regard, David Basinger has argued: "With respect to our basic needs [such as food, health, and shelter] it is never justifiable for God to withhold that which he can and would like to give us until petitioned" $(2003,267)$. If so, it could never be the case that petitionary prayer counterfactually influences the omnibenevolent God to provide the basic needs of humans. But, then, the many petitionary prayers that Christians aim at (counterfactually) influencing God to provide basic needs would be inconsistent with the affirmation that God is omnibenevolent. Can one coherently affirm that petitionary prayer might influence the omniscient, omnipotent, and omnibenevolent God to bring about some good that he otherwise would not bring about-particularly relative to basic needs or the prevention of great evils?

\section{Some Approaches to the Influence Aim Problem of Petitionary Prayer}

\footnotetext{
${ }^{8}$ Davison and Cohoe disagree, however, on what counts as efficacious prayer. Davison offers a contrastive reasons account wherein "S's petitionary prayer (token) for an object $\mathrm{E}$ is answered by God if and only if God's desire to bring about $E$ just because $S$ requested it plays an essential role in a true contrastive explanation of God's bringing about E rather than not" $(2017,38)$. However, Cohoe criticizes Davison's account in numerous respects and argues prayer could be effective even in cases "in which God already has conclusive reasons for bringing about the object of prayer," analogous to when a wife's request provides an additional reason with deliberative weight for her husband to do something, even if her husband would have done so whether she requested it or not $(2018,173$; cf. Cohoe 2014, 37-39). Davison responds that his account does not rule this out as a possibility but expresses "puzzlement about what is possible here" $(2018,189)$. Because my article focuses on cases that involve counterfactual dependence, the success or failure of my proposal does not hinge on what account of efficacious prayer one prefers.
} 


\subsection{Denying Some Premise(s)}

One way to elude the IAP is to deny divine omnibenevolence, omnipotence, omniscience, or the influence aim. First, one might maintain that petitionary prayer may somehow inform God. This would elude the IAP, but at the cost of denying divine omniscience. ${ }^{9}$ Instead, one might claim that God could be influenced to desire to bring about a good he otherwise would not have desired. This would elude the IAP, but at the (potential) cost of denying divine omnibenevolence, understood to mean that God wills all optimal compossible good(s) or, if there is no best or optimal set of compossible good(s), God wills a set of goods than which no other set of compossible goods is morally better.

Alternatively, one might claim that God lacks the sheer power to bring about the good(s) that he wills to bring about, but petitionary prayer somehow increases God's power. This would elude the IAP, but at the cost of denying divine omnipotence. Further, such a move would raise the puzzling question as to how prayer could increase God's power. In this regard, the process theist Marjorie Hewitt Suchocki avers, "when God needs resources for any particular situation, God will give an impulse toward prayer to those open to such an impulse so that their praying may make a difference to what God can give in yet another place" $(1996,49)$. Yet, to claim that "God needs resources" seems to conflict with divine omnipotence, at least as traditionally understood. ${ }^{10}$

Most Christian theists do not consider a denial or significant modification of any of premises (1)-(3) to be a live option. Instead, to address the IAP many Christian theists deny the influence aim. ${ }^{11}$ Some may deny the usefulness of petitionary prayer altogether. Many others, however, deny the influence aim, adopting the view that petitionary prayer does not influence God but may positively affect the human who prays or hears such prayer (e.g., by bringing human desires more in line with God's will and in other ways). ${ }^{12}$ This follows the common adage that prayer does not change God, but it changes us. Indeed, for some Christian theists, it is metaphysically impossible that prayer could affect God or have any real influence on what God brings about. $^{13}$

\footnotetext{
${ }^{9}$ Some argue that if God possesses exhaustive definite foreknowledge (EDF), the (counterfactual) influence aim of petitionary prayer is pointless. This objection, however, depends on whether EDF requires that prayer could not counterfactually influence divine action. This matter of considerable dispute cannot be adequately addressed in this brief article. For a discussion, see DiRoberts (2019). See also Flint $(1998,212-28)$.

10 Many process theists deny divine omnipotence or offer a non-traditional conception of omnipotence wherein God possesses the maximum power that could be possessed given process metaphysics but lacks power to prevent the evils in this world. See Hartshorne (1984) and Griffin (2004). Cf. Oord (2015).

11 Thinkers from a wide variety of perspectives deny the influence aim. For a discussion of traditional Reformed approaches that do so, see Woznicki (2018). See also Crisp (2010, 133-55).

${ }^{12}$ See the discussion in Woznicki (2017) and Woznicki (2018).

13 The relationship between petitionary prayer and various forms of Christian theism relative to divine attributes such as aseity, simplicity, eternity, immutability, impassibility (and others) warrants a discussion all its own, which cannot be adequately undertaken in this brief article.
} 
However, other Christian theists are committed to all four premises, with some affirming the influence aim as the view most consistent with Christian practice and numerous instances in Scripture that appear to support the view that prayer might make a difference regarding whether or not God brings about some good (e.g., 2 Chron 7:14; Mark 9:29; Luke 11:1-13). Given the limited scope of this article, I will leave aside the debate over whether Scripture and/or the Christian tradition provides warrant for affirming the influence aim. ${ }^{14}$ Instead, the remainder of this article focuses on some potential ways in which the Christian theist who affirms the influence aim of petitionary prayer (including with respect to basic needs and the prevention of great evils) might do so in a way consistent with divine omniscience, omnibenevolence, and omnipotence.

\subsection{Adding One or More Additional Premises}

Instead of denying any premises of the IAP, one might argue that the four premises are not inconsistent. One might attempt to show this by positing that there is some other premise by which the influence aim can be consistently affirmed alongside divine omniscience, omnibenevolence, and omnipotence. ${ }^{15}$ For example, in addition to premises (1)-(4), one could posit:

(5) God's providence is ordered in such a way that there is some good that God perfectly knows about, prefers to bring about, and possesses the sheer power to bring about, yet God has some reason(s) compatible with his perfect goodness such that he will not bring about that good without the "influence" of petitionary prayer. ${ }^{16}$

At this juncture, one might argue along the lines of the skeptical theist defense relative to the problem of evil. That is, one might be skeptical regarding the ability of humans to make sufficiently knowledgeable judgments regarding why God has acted, or refrained from acting, as he has. ${ }^{17}$ One inclined in this direction might thus affirm (5) while also believing that humans should not expect to be in a position to know God's reason(s) for refraining from bringing about such good(s) in the absence of petitionary prayer.

Yet, many have posited accounts along the lines of premise (5) that go beyond such an appeal to inscrutability. In her seminal essay on petitionary prayer, Eleonore Stump suggests that petitionary prayer is an important ingredient to foster true friendship between God and humans. She contends that, absent some benefits being

\footnotetext{
${ }^{14}$ For a discussion of some of the biblical material on petitionary prayer, see Crump (2006) and the essays in Longenecker (2001).

15 There are too many nuanced proposals to adequately consider them all here. In what follows, I restrict the discussion to some representative proposals.

${ }^{16}$ This premise is compatible with numerous approaches to divine providence and action, including the traditional understanding of primary and secondary causality. See Cocksworth's $(2018,162-167)$ discussion of this in terms of a non-competitive relation between divine and human agency. See also Crisp $(2010,150-55)$ and Woznicki $(2017,346)$.

17 On skeptical theism, see Dougherty and McBrayer, eds. (2014).
} 
contingent upon humans asking God for them and not being guaranteed that God will grant such requests, God might either "completely dominate" the human in such relationship or the human may be "spoiled" and relate to God as a "personal power source," either of which would undermine true friendship of the kind God seeks $(1979,87) .18$

Yet, Stump notes that her account leaves difficult questions unanswered relative to the broader problem of evil $(1979,89-90) .{ }^{19}$ Thus, while her account might succeed in providing an avenue that coherently affirms that God might sometimes bring about some good he otherwise would not have in response to petitionary prayer, its usefulness does not appear to extend to accounting for the coherence of prayers that petition God to provide some basic need or to prevent some great evil, which amounts to a fair portion of the petitionary prayers about which many Christians are most concerned.

Further, Nicholas D. Smith and Andrew C. Yip contend that proposals that focus on sustaining the right kinds of relationships (such as Stump's proposal) are unsatisfying because "they tend ... to overlook the possibility of achieving such relationships in ways other than prayer" $(2010,408) .{ }^{20}$ Smith and Yip offer an alternative proposal that focuses on the additional value of "partnership with God" to bring about goods in the world, engendered by God making some goods contingent upon petitionary prayer of the kind that those praying commit to doing what they can to bring about the prayed-for outcome $(2010,404-408)$. On this proposal, petitionary prayer allows individuals to partner with God with respect to goods beyond their ability to bring about themselves.

This kind of proposal hinges on the view that it is more valuable for God to bring about some good in partnership with creatures than to do so immediately by himself. ${ }^{21}$ In this regard, Caleb Murray Cohoe makes a convincing argument that "prayer can add a distinctive sort of value to the world that would not be present otherwise" (Cohoe 2014, 36n22). Going beyond Smith and Yip's proposal, Cohoe addresses petitionary prayer as part of the broader discussion of divine and creaturely causation and makes a compelling case that "petitionary prayer is a distinct way for us to cause things, by asking God for them, and, thus, it makes the causal order of things more complete and diverse, better displaying God's goodness" (Cohoe 2014,33). As noted earlier, he argues that petitionary prayer might effectively

\footnotetext{
${ }^{18} \mathrm{Cf}$. Reibsamen's argument along these lines that counterfactually "efficacious petitionary prayer can uniquely enhance the divine-human relationship" in terms of shared attention and joint action, including a triadic kind of shared attention related to petitionary prayers for third parties (Reibsamen 2019, 138-42). Reibsamen's account, however, does not address whether such enhancement would be morally sufficient relative to prayer for basic needs or regarding evils.

${ }^{19}$ For Stump's broader account relative to the problem of evil, see Stump 2012.

${ }^{20} \mathrm{Cf}$. the proposal of Murray and Meyers (1994), which Smith and Yip also criticize along these lines. See also Gianluca di Muzio's argument that such "indirect benefit account[s]" fail because "the indirect benefits of petitionary prayer are disconnected from its [counterfactual] efficacy" (di Muzio 2018, 42).

${ }^{21}$ Cf. Daniel and Frances Howard-Snyder's argument that petitionary prayer might itself be of sufficient value for God to make some things contingent on petitionary prayer "because, in general, it is a good thing for us to be responsible for our own welfare and the welfare of others and, as Richard Swinburne observes, the institution of petitionary prayer helps to serve that purpose" $(2010,51$; see also Swinburne 1998, 115).
} 
contribute additional value even in the absence of counterfactual dependence, but he also notes that "many important cases of petitionary prayer do involve counterfactual dependence" (Cohoe 2014, 38).

Even if petitionary prayer does add some distinctive and significant value, however, one might ask whether such added value is sufficient relative to divine omnibenevolence when it comes to prayers aimed at influencing God to supply basic needs or prevent great evils that he otherwise would not have. Smith and Yip recognize this significant worry, but note that they do not "intend" their proposal "to respond directly" to the problem of evil $(2010,396)$. Cohoe similarly notes that his account does not address the evidential problem of evil or God's action relative to "the distribution of goods" (Cohoe 2014, 40). ${ }^{22}$ As such, remaining questions regarding the (counterfactual) influence aim of petitionary prayer relative to basic needs and evils do not count against Smith and Yip's account or Cohoe's account as they delimit them, but do call for further exploration.

Moreover, while agreeing "that prayer might make an event more valuable," Martin Pickup has recently criticized proposals that claim petitionary prayer might be effective relative to counterfactual dependence because such prayer increases the world's overall value. Specifically, Pickup argues that such proposals (explicitly or implicitly) affirm "that God will choose to actualise an event if and only if it is overall better that it occurs than not" $(2018,93) .{ }^{23}$ If such proposals are so committed (and whether they are may be challenged), then "before the prayer the overall value of the prayed-for event is no higher than it not coming about," but the added value of petitionary prayer itself tips the scales to make actualizing the prayed-for outcome more valuable overall $(2018,93) \cdot{ }^{24}$ Accordingly, Pickup contends, "on these models petitionary prayer only has a self-fulfilling benefit: prayer is effective [relative to counterfactual dependence] simply because of the benefits that answered prayer has, independent of the outcomes prayed for" $(2018,93)$. Yet, he contends, this "circularity" is "philosophically unsatisfying" and "wildly at odds with the actual practice of petitionary prayer" $(2018,94)$.

Pickup's proposed way forward is to jettison the affirmation that "God chooses to actualise [some event] $e$ if and only if $e$ is overall better to occur than not" (Pickup 2018 , 95). Instead, Pickup adopts the view (widespread in the literature on the problem of evil) that in some cases there may not be a determinate better overall outcome relative to whether a given event occurs or not, but the overall value of both outcomes may be incommensurable. If so, "God's choice whether to actualise the event or not cannot be determined solely on the basis of value," but one's "prayer

\footnotetext{
${ }^{22}$ Again, Cohoe's account does not require counterfactual dependence; "God may provide many of the same things he gives to those who pray to those who do not petition him," including basic needs (2014, 40).

23 Pickup's argument here relates only to efficacy considered relative to counterfactual dependence and thus does not apply to Cohoe's account in general. Pickup's account also does not consider that it might be better for an event to occur in itself, but it might be worse for God to make that event occur. ${ }^{24}$ Cf. Parker and Rettler's proposal that God might be "ambivalent between world X (where he performs A) and world Y (where he performs B), because both are equally as good or could be made equally as good" such that petitionary prayer might influence which world God "picks" when the goodness of two or more possible worlds is equal $(2017,185)$.
} 
might give God a reason to choose that the event occur rather than not, and hence the event could counterfactually depend on the prayer" $(2018,98)$. Yet, he claims, this renders "unnecessary" proposals that claim petitionary prayer adds to the world's overall value $(2018,102)$.

I agree with Pickup that it is a mistake to assume that God chooses to actualize this or that outcome solely on the basis of overall value and I further agree that the value of some outcomes may be incommensurable from God's perspective. ${ }^{25}$ Accordingly, throughout this article I deliberately refer what God may prefer (for whatever reasons consistent with omnibenevolence), in contrast to the supposition of some best possible good. However, Pickup's proposal does not offer much help relative to instances of petitionary prayer for basic needs or the prevention of evils. While in some instances whether God brings about this kind of prayed-for outcome or not may be of incommensurable value overall, not all such instances are of incommensurable value overall (as Pickup himself recognizes). ${ }^{26}$ For example, in at least most cases, it would be better overall if a starving child had food to eat. If so, one could grant that there may not be a best overall value, while also affirming that in many specific cases there is a determinate outcome that is better overall than the alternative.

Additionally, one could simply affirm that God's decision-making is dependent upon whether it would be morally good or evil (all things considered) for God to perform or refrain from performing some action, while recognizing that in some cases whether or not God acts in some way might be morally ambivalent. If omnibenevolence entails that God only does good and never does moral evil, as I believe it does, then the goodness of a given action would be a necessary (but not sufficient) condition of the omnibenevolent God performing that action while the evilness of performing or refraining from performing a given action would be a necessary and sufficient condition of God not performing or not refraining from performing a given action, respectively.

If this is so, then some prayers might petition God to perform an action that it would be morally evil for God not to perform if he could do so without otherwise compromising his perfect moral goodness. For example, it might be that in some cases God has a moral duty to prevent great evils if God can do so without compromising his own moral goodness (e.g., if doing so would require breaking a promise) or bringing about an equal or greater evil. Likewise, it might be that God has a moral duty to provide for the basic needs of humans if he can, unless he has some morally sufficient reason(s) for not doing so. One could argue that God does not have any such moral duties, but in what follows I will suppose that the omnibenevolent God does have such moral duties, at least in some cases (while recognizing that humans are often not in a position to know just what moral duties God may have in a given situation).

${ }^{25}$ I have elsewhere suggested this as a possibility relative to the problem of evil. See (Peckham 2018, 143).

26 Pickup "agree[s] that prayer might make an event more valuable. So whether an event is better to occur or not might indeed counterfactually depend on a prayer for that event" $(2018,90)$. 
If so, despite the many valuable contributions of the foregoing proposals regarding the broader problem of petitionary prayer, the IAP remains a problem (at least) for cases of petitionary prayers that aim at (counterfactually) influencing God to perform an action that would be morally evil for God not to perform if he could do so without otherwise compromising his perfect moral goodness (as some claim is the case regarding prayers for basic needs or the prevention of evils). This is because, whether petitioned to do so or not, the omnibenevolent God would perform any action that it would be morally evil for God not to perform if he could do so without otherwise compromising his moral goodness. In this and other regards, the foregoing proposals leave the (counterfactual) influence aim relative to the many prayers Christians offer for basic needs or the prevention of evils largely unaddressed and thus, at least with respect to such instances, do not resolve the IAP that is the focus of this article.

However, one might propose an additional premise that is compatible with some of the foregoing proposals. Specifically, one might posit:

(6) There is some factor or set of factors that morally prevents God from bringing about what he already prefers to bring about, but petitionary prayer makes a difference relative to the preventing factor(s). ${ }^{27}$

The possibility that God may be prevented from bringing about some state of affairs is sometimes overlooked due to the mistaken assumption that if God is omnipotent, God can bring about whatever good state of affairs he pleases. However, as Alvin Plantinga has argued in his famed free will defense relative to the logical problem of evil, bringing about some good(s) may not be up to God because some good(s) might be intrinsically contingent on the free decisions of creatures (1977, 34 ). If so, there might be some good that the omniscient, omnibenevolent, and omnipotent God prefers to bring about, but which is not strictly up to God to bring about.

One might, then, posit a kind of free will defense relative to the IAP. ${ }^{28}$ It might be the case that God has committed himself to consistently granting to some creatures a kind of free will such that some divine "interventions" may only occur in response to petitionary prayer. For example, W. Paul Franks has posited that perhaps "God has restricted his powers of interaction with humankind in such a way that those powers are exercised only in response to promptings from humankind" $(2009,322)$. Franks adds, "If we understand" this "to be a self-imposed restriction, then there is no inconsistency between it and God being all-powerful. It is not that God cannot interact with humankind without being prompted to do so; it is that he has decided not to do so" (322, emphasis original).

For this kind of defense to work, however, there must be some morally sufficient link between creaturely free will and those goods that God would bring about only in response to petitionary prayer. Otherwise, critics of the influence aim

${ }^{27}$ Again, I use "prefers" in a way that does not require the supposition of a best possible world or a best possible good in every case.

${ }^{28}$ See, e.g., Brümmer (2008, especially 74-81). 
will argue, God ought to bring those goods about whether or not anyone petitions him to do so. It may be, in this regard, that there are some good(s) that God might prefer to bring about, but such good(s) would impinge upon the divinely granted free will of some creature(s), unless the creature(s) grant(s) God permission to do so.

If this kind of free will defense works relative to the IAP, it appears that its effectiveness might be limited to the influence aim of prayers offered by creature(s) who are in a position to grant permission with regard to the free will of the creature(s) that would otherwise be impinged upon. As such, this defense may work for petitionary prayers offered for oneself, if one can grant permission with respect to what falls within the purview of one's free will. However, it is difficult to see how it could be effective for many other kinds of petitionary prayers, particularly prayers petitioning God to bring about some good(s) for others (i.e., intercessory prayers). Many Christian theists might argue that parents might be in a position to grant God permission relative to the free will of their young children, and some might extend this limited permission-granting function to some closely related proxies for others, particularly those who might be unable to grant permission for themselves. However, even if this much is granted, it would cover only a narrow set of petitionary prayers for others, a far more circumscribed set than frequently encountered in Scripture and everyday Christian practice.

Yet, one might argue that I could also petition God to bring about some good(s) for others in some way that does not impinge upon their free will. For example, I might pray to God to keep a friend safe during a tornado, alongside the assumption that God might do so in numerous ways that do not impinge on my friend's free will (e.g., by calming or diverting the storm, miraculously shielding my friend, or by an advance special revelation to my friend to position herself somewhere safe from the storm). ${ }^{29}$ However, this brings us back to the objection that God ought to bring about such goods (if they are indeed preferable given what God knows) whether or not anyone petitions him to do so. If what I am petitioning God to bring about for my friend does not impinge upon her free will in the first place, then such a petition does not appear to fall within the bounds of a basic free will defense relative to the IAP. Aside from an appeal to inscrutability, making sense of the (counterfactual) influence aim of these kinds of prayers and many others that appear in Scripture and common Christian practice would seem to require some further line of argument.

Here, one might consider extending accounts that propose petitionary prayer adds some value to the world in a way that Pickup's criticism of such accounts did not address. Specifically, one could propose that God has a morally sufficient reason for committing himself to consistently operate in a way conducive to true friendship, partnership with God, and/or relative to bringing about goods through secondary causes such that, in virtue of God's commitment, God is morally prevented from

\footnotetext{
${ }^{29}$ Some may argue that such interventions would undermine the kind of epistemic distance and/or law-like regularity they take to be necessary for free will and/or some other good(s). However, if God would never so intervene, then one should deny the influence aim with respect to the many prayers Christians offer petitioning God to so intervene. Alternatively, the advocate of the influence aim may pray on the belief that God may intervene sometimes (even if exceedingly rarely).
} 
bringing about certain goods in the absence of petitionary prayer. ${ }^{30}$ If it would be immoral for God to do otherwise than keep his commitments, then any promise or commitment God makes would effectively (morally) limit God's action. If God has committed himself in this way, then petitionary prayer might make the difference regarding God actualizing some good outcome, not strictly in the sense that the additional value of any given petitionary prayer tips the scales to make the prayedfor outcome sufficiently more valuable overall, but in the sense that petitionary prayer might make it the case that God is no longer morally prevented from bringing about that good outcome. ${ }^{31}$

Such a scenario faces many questions, however, including what such a morally sufficient reason for God morally committing himself in this way might be. Further, absent some coherent account wherein petitionary prayer sometimes removes the moral impediment to a particular kind of divine action and sometimes does not, extending such accounts in this way would only work relative to the provision of goods or prevention of evils of the kind that God has morally restricted himself from bringing about except in response to petitionary prayer. This means that such an account would not apply to any goods that God sometimes brings about in the absence of petitionary prayer, which (at least on most Christian accounts of divine providence) would seem to encompass a great many important goods (including basic needs) about which Christians often pray.

Yet, perhaps there is some larger context in which God has committed himself to act in certain ways that would bring about certain goods or prevent evils only in response to petitionary prayer and only under certain conditions that are fluid in a way that does not depend on petitionary prayer itself or merely upon God's preferences. That is, perhaps there is some larger context in which God has committed himself such that petitionary prayer sometimes morally justifies God in bringing about some good or preventing some evil that God would otherwise be morally prevented from bringing about or preventing. If so, petitionary prayer might sometimes provide God the moral leeway to strongly intervene in response to petitionary prayers.

At this juncture, I believe the discussion might be advanced by retrieval of the biblical and traditional (but oft-neglected) motif of cosmic conflict. ${ }^{32}$ That is, the biblical and traditional portrait of a cosmic conflict between God and celestial

\footnotetext{
30 Cf. Cohoe's Best-Ordering Principle; "God has given things he has chosen to create the most appropriate order, one that cannot be improved upon" $(2014,29)$. Given this principle, "God must allow the things he has created to exercise their causal powers, since a world in which God denied these created things the exercise of their powers would not be as well ordered" $(2014,31)$.

${ }^{31}$ This might be complemented by Geoffrey Cupit's (1994) argument that both requests and promises may create obligations. Daniel and Frances Howard-Snyder (2011) argue, if Cupit's account is correct, "then asking God to do something can change the moral status of his doing it" $(2011,67)$. Cf. Scott Hill's proposal that a "non-trivial number of petitionary prayers are such that the praying subject overall deserves what God has already decided to give that subject partly in virtue of asking" (Hill, 2018 409). ${ }^{32}$ Plantinga raises cosmic conflict as a possibility (drawing on Augustine), particularly with respect to natural evil (see, e.g., 1974, 192). However, most scholarly discussions do not consider cosmic conflict. Terrance Tiessen discusses something like a cosmic conflict approach, which he calls the "church dominion model," but notes this model "is represented in popularly written works on prayer rather than in scholarly treatises on providence." $(2000,119)$.
} 
creatures in rebellion against God may provide a context in which it makes sense to hold that the omnipotent God is sometimes "morally" impeded from bringing about some goods unless petitionary prayer is offered, but the efficacy of such petitionary prayer (relative to counterfactual dependence) is contingent upon other fluid conditions that God does not unilaterally determine. To this we now turn.

\section{A Cosmic Conflict Approach to Petitionary Prayer}

\subsection{The Cosmic Conflict and the Rules of Engagement}

In traditional forms of Christian theism, God has an enemy who is believed to be a fallen angel, a celestial creature who was created morally perfect, freely rebelled against God and led other angels into an ongoing rebellion. In both Scripture and Christian tradition, this enemy is identified as the devil, called Satan, and portrayed as the ruler of demons (cf. Matt 12:24; Rev 12:7-9). ${ }^{33}$ Jesus himself refers to the devil as "the ruler of this world" (John 12:31; 14:30; 16:11) and, in the temptation narrative, the devil claims that "all the kingdoms of the world" have been "handed over to" him as a "domain" and, he claims further, "I give it to whomever I wish" (Luke 4:5-6). ${ }^{34}$ The gospels are filled with instances of cosmic conflict. As Brian Han Gregg puts it, the "conflict between God and Satan is clearly a central feature of Jesus' teaching and ministry" (Gregg 2016, 66; see, e.g., Matt 4:1-11; cf. Matt 13:27-30, 3743). ${ }^{35}$

In this regard, C.S. Lewis notes: "One of the things that surprised me when I first read the New Testament seriously was that it talked so much about a Dark Power in the universe-a mighty evil spirit who was held to be the Power behind death and disease, and sin," who "was created by God, and was good when he was created, and went wrong." Accordingly, Christianity teaches that "this universe is at war," but it is not "a war between independent powers ... it is a civil war, a rebellion" and "we are living in a part of the universe occupied by the rebel. Enemy-occupied territory-that is what this world is" $(1952,45)$.

Yet, the very concept of a cosmic conflict raises questions regarding how there could be any conflict between the omnipotent God of Christian theism and mere creatures. If God is omnipotent, no one could oppose God with respect to sheer power-there could be no cosmic dualism. Instead, a cosmic conflict is possible only if God grants creatures some power to oppose him. As such, the cosmic conflict must not be conceived of as a conflict of sheer power, but as a conflict of some other kind. The conflict might be understood as a challenge by the devil against the justice of God's government, involving a cosmic courtroom drama wherein Satan has slandered God's character in the heavenly court, alleging that God's government is not perfectly

\footnotetext{
${ }^{33}$ Jeffrey Burton Russell avers, "the devil has always been a central Christian doctrine, an integral element in Christian tradition" $(1981,226)$.

${ }^{34}$ Unless otherwise noted, Scripture quotations are from the NASB.

35 The cosmic conflict motif in Scripture has been well-documented. See, e.g., Arnold (1992), Boyd (1997), Gatumu (2008), Heiser (2015), and Peckham (2018).
} 
just. ${ }^{36}$ This would be consistent with texts that indicate that Christ came "to testify to the truth" (John 18:37), to demonstrate God's righteousness and love (Rom 3:25-26; 5:8), "to destroy the works of the devil" (1 John 3:8), and to "destroy the one who has the power of death, that is, the devil" (Heb 2:14).

Even as a city mayor accused of corruption could not defeat the allegations against him at an epistemic level by a show of force, it may be that, by their very nature as epistemic claims, the devil's slanderous charges against God's justice could not be settled by an exercise of divine power, but required some open demonstration. Since an omnipotent God would possess the power to immediately silence any allegations and remove any challengers, it might be that in order for any creature to make a case against the omnipotent God, creatures must be granted some temporary and limited parameters within which to operate. Such parameters might be referred to as rules of engagement, which afford the devil some power and limited jurisdiction that the devil cannot exceed, but which also morally limit the exercise of God's power insofar as God has committed to granting such parameters. This would be consistent with what Scripture refers to as "the domain of darkness" (Col 1:13) or "the dominion of Satan" (Acts 26:18; cf. Matt 12:24-29; Eph 2:2; 2 Cor 4:4; 1 John 5:19; Rev 13:2-8).

For the purposes of this essay, the rules of engagement may be defined as those parameters to which God has committed himself in relationship to creatures, for the good of all concerned, including any commitments God has made regarding the extent of rulership and jurisdiction temporarily afforded to the rebels in the cosmic conflict. Against this background, we are now in a position to consider some implications of this rules-of-engagement framework regarding the influence aim of petitionary prayer.

\subsection{The Rules of Engagement and the Influence Aim Problem of Petitionary Prayer}

Suppose there is a cosmic conflict with rules of engagement as described above, rules which grant some limited jurisdiction or domain to the devil and his cohorts while correspondingly limiting (morally) the parameters within which God acts in the world. Suppose, further, that such rules of engagement are set up such that petitionary prayer might increase God's (moral) jurisdiction to intervene in ways that, absent such prayer, would not have been morally available to God.

Perhaps the rules of engagement include something like the "trigger clauses" that are sometimes found in legal contracts, wherein a particular provision of the contract is "triggered" or activated by some contingent factor (e.g., a professional basketball player's contract, wherein the player is eligible for a higher maximum value contract if he wins the Most Valuable Player Award). If so, perhaps petitionary prayer somehow "triggers" a clause in the rules of engagement such that God can morally bring about some good or goods that he already wanted to bring about, but was morally prevented from doing so by the rules of engagement.

\footnotetext{
${ }^{36}$ Scripture identifies the devil as a slanderer and "accuser" in the heavenly court (Rev 12:10; cf. Job 1-2; Zech 3:1-2; Jude 9).
} 
If there are rules of engagement that are dynamically related to other factors, including some human actions that might "trigger" provisions in the rules of engagement, then whether God can (morally) bring about a particular good in a particular situation may depend (at least in part) upon whether humans have petitioned him to do so. That is, the rules of engagement might be set up such that some things temporarily fall within the jurisdiction of the demonic realm, but the limits of this jurisdiction might be dynamically related to how humans relate to God. If so, petitionary prayer may grant God additional permission or open up avenues for God that were not previously (morally) available to him within the rules of engagement. ${ }^{37}$

At first glance, such a proposal may seem outlandish to some. However, the view that there is a cosmic conflict wherein the devil has some significant degree of temporary rulership is quite at home in Scripture and the Christian tradition. Yet, given God's omnipotence, for the devil to actually function as a ruler in any genuine sense of the term, there must be some parameters within which the devil is allowed to rule. If so, there may also be provisions within such rules wherein God reserves the right to intervene in particular circumstances, some of which might depend on how humans relate to God via prayer and otherwise.

For example, in Mark 9, the disciples ask why they were unable to cast out an unclean spirit that Jesus cast out and Jesus replies, "This kind cannot come out by anything but prayer" (Mark 9:28-29). This suggests that prayer makes a difference relative to whether or not some kinds of unclean spirits can be cast out, which seems to suggest there are parameters within which such spirits operate and such parameters may be affected by petitionary prayer. Numerous other passages also appear to indicate that some impediments on divine action are tethered to petitionary prayer and/or belief (cf. Matt 21:22; Mark 11:22-24; Matt 17:20; Mark 6:5). Elsewhere, the unbelief of people in Christ's hometown of Nazareth appears to limit his miracle-working there such that "He could do no miracle there except that He laid His hands on a few sick people and healed them. And He wondered at their unbelief" (Mark 6:5-6; cf. Matt 7:7-8; 1 Thess 2:10; 2 Chron 7:14). Further, after informing Peter that "Satan has demanded permission to sift you like wheat," Jesus tells Peter, "but I have prayed for you, that your faith may not fail" (Luke 22:31-32).

Elsewhere, human activities are spoken of as if they might affect the parameters in which Satan and his cohorts are permitted to operate. For instance, Ephesians 4:27 exhorts, "do not give the devil an opportunity." Later in Ephesians, believers are instructed: "Put on the full armor of God, so that you will be able to stand firm against the schemes of the devil. For our struggle is not against flesh and blood, but against the rulers, against the powers, against the world forces of this darkness, against the spiritual forces of wickedness in the heavenly places" (Eph 6:11-12; cf. Dan 10). Just a few verses later, believers are further instructed: "With all prayer and petition pray at all times in the Spirit" and "be on the alert with all perseverance and

\footnotetext{
37 On this account, it would make sense to offer petitionary prayer with the influence aim even for things that God might bring about in the absence of petitionary prayer, because the one praying would not know whether there are moral impediments (e.g., whether some particular area temporarily falls within the jurisdiction of the demonic realm) in a given situation that might be impacted by such petitionary prayer.
} 
petition for all the saints" (Eph 6:16, 18; cf. 19-20). James 4:7-8 exhorts, further, "Submit therefore to God. Resist the devil and he will flee from you. Draw near to God and He will draw near to you" (cf. Matt 6:10-13). Such texts may be read as indicating that, at least in some cases, how humans relate to God-in prayer and otherwisemakes a difference relative to what the devil and his cohorts are permitted to do and relative to God's protection against the attacks of the demonic realm.

For example, rules of engagement might be in the background when God specifies the covenantal parameters of his blessings toward Israel, particularly relative to God's declaration in 2 Chronicles 7:14 that, "if my people who are called by name humble themselves, pray, seek my face, and turn from their wicked ways, then I will hear from heaven, and will forgive their sin and heal their land" (NRSV; cf. Dan 9:13). It might be that the demonic realm has more jurisdiction to antagonize Israel (directly or through surrounding nations) if the people have removed themselves from proper covenant relationship with God, but if God's people would sufficiently humble themselves and pray, then provisions in the rules of engagement would be triggered such that God could bring about goods for their sake that otherwise would not have been morally permissible within the rules of engagement.

Another example of how, in certain circumstances, specific prayers might make a difference on this rules-of-engagement model appears in Daniel 10. Therein, an angel sent from God appears to Daniel in response to Daniel's petitions to understand a revelation about "great conflict" (Dan 10:1,12; cf. 9:3-23). Yet, the angel was delayed for three weeks because "the prince of the kingdom of Persia," whom many biblical scholars identify as a celestial being working in opposition to God, "was withstanding" the angel "for twenty-one days," until Michael the prince "came to help" the angel (Dan 10:12-13). While the omnipotent God possesses the power to immediately answer Daniel's petition, it might be that celestial beings on both sides of the conflict operate in accordance with specific rules of engagement such that Daniel's petitions made it morally permissible for God to effectively send an angelic messenger to Daniel despite the enemy's opposition.

Such hypothetical examples should not be mistaken as claims regarding the way petitionary prayers actually work but are simply examples of the way petitionary prayer might relate to rules of engagement. I do not reference this or other biblical material as proof of this rules-of-engagement approach. These and other biblical passages demand further consideration in their own context as well as extensive biblical and theological analysis. In this article, I merely seek to put this avenue on the table as one possible approach that I believe warrants further consideration. For such an approach to warrant further consideration relative to the IAP, it only needs to be the case that such a cosmic conflict scenario is possible and compatible with affirming (1-4).

Whatever one thinks of these biblical passages, or the cosmic conflict framework more broadly, I contend that such a scenario is both possible and compatible with (1-4). Given such a scenario, whether or not God can (morally) intervene to prevent some disaster or provide a special revelation might be limited according to the rules of engagement, which themselves might be dynamically related to petitionary prayer (and other factors). On such a scenario, God might otherwise 
prefer to bring about a particular good (or prevent a particular evil) but in some cases doing so might be against the rules of engagement unless God is petitioned to do so.

This might be put in the form of the following premise:

(7) It might be that God has committed himself to rules of engagement in a cosmic conflict context such that God is morally prevented from bringing about some good(s) that he is aware of, otherwise would like to bring about, and possesses the sheer power to bring about, unless he is petitioned to do so by an appropriate party or parties.

On this understanding, the influence aim is consistent with divine omniscience, omnibenevolence, and omnipotence. More specifically, it is consistent with:

(a) omniscience, because it is consistent with the belief that God is always entirely aware of the object of petition.

(b) omnibenevolence, because it is consistent with the belief that God already otherwise prefers to bring about the potential good that is the object of petition. ${ }^{38}$

(c) omnipotence, because it is consistent with the belief that God essentially possesses the sheer power to bring about the potential good that is the object of petition.

On this understanding, then, one might offer petitionary prayer in a way that is consistent with divine omniscience, omnibenevolence, and omnipotence, denying that such a prayer might inform God of humans' desires or needs, convince God to actualize some good he did not already otherwise prefer to actualize, and/or increase God's power to actualize said good. Instead, given a rules-of-engagement framework, one might believe that absent petitionary prayer, in some cases God might be morally prevented from bringing about some good(s). Yet, petitionary prayer might provide God moral jurisdiction within the rules of engagement to bring about some good(s) and thus might influence whether or not God brings about such good(s) in a way that appears to be entirely consistent with divine omniscience, omnipotence, and omnibenevolence.

Such an approach may also shed light on why God sometimes does not answer petitionary prayers in the way one might think that he should-particularly relative to petitions for apparently good things that God does not bring about. This issue demands extended treatment of its own, but a few brief comments might highlight the further potential usefulness of a rules-of-engagement framework relative to petitionary prayer.

First, it is important to remember that "we do not know how to pray as we should" (Rom 8:26). At times, prayers may not be answered as we expect or desire

\footnotetext{
${ }^{38}$ One might question whether it was entirely good for God to commit himself to such rules of engagement. For this cosmic conflict approach to work, it only needs to be possible that God has a morally sufficient reason for so committing himself. I have made some suggestions in this respect elsewhere (see Peckham 2018, 147-49).
} 
because we might be praying for the wrong outcome that is not in accordance with those good(s) God prefers (cf. 1 John 5:14-15) and/or with the wrong motivation. ${ }^{39}$ While James 4 states, "You do not have because you do not ask," James also states, "You ask and do not receive, because you ask with wrong motives" (James 4:2-3). What one prays for might not actually be good for oneself or for others concerned and humans are often not in a position to know what range of good options are available for God to bring about, some of which may be equally good and/or of incommensurable value overall.

Second, it might be that some things we petition God to do would contravene God's commitment to granting and respecting creaturely freedom and/or causal agency. Third, it might be that there is a cosmic conflict and God has committed himself to rules of engagement such that God is morally prevented from bringing about some good(s) that he otherwise would prefer to actualize and possesses the power to actualize, and in some cases even petitionary prayer offered faithfully by an appropriate party or parties does not morally permit God to do so. In this regard, while prayer may open up additional avenues for God, there are many other factors involved such that one should be very careful to avoid reducing the issue of whether or not God actualizes some good to the single factor of petitionary prayer. Some divine actions might remain in conflict with the rules of engagement or otherwise be morally unavailable or less than preferable, regardless of how faithfully and how much believers pray (cf. Matt 26:38; Luke 22:32).

In brief, God might be morally prevented from bringing about some apparent good that God knows of, prefers (in and of itself), and possesses the sheer power to bring about if:

(a) doing so would not actually be for the divinely preferred overall good of all concerned, perhaps resulting in greater evil or diminishing of the good(s) God prefers,

(b) doing so would contravene creaturely freedom and/or causal agency of the kind God has committed to for some morally sufficient reason(s), and/or

(c) doing so would conflict with the rules of engagement in a cosmic conflict, even given petitionary prayer offered faithfully by an appropriate party or parties.

This brief articulation and discussion of a cosmic conflict rules-of-engagement approach raises many other questions, but I believe it offers a possible avenue relative to the IAP that is typically not considered in contemporary treatments of petitionary prayer but is worthy of consideration.

\footnotetext{
${ }^{39}$ See Thomas P. Flint's argument relative to the value of middle knowledge for accounting for the problem of unanswered prayers (1998, 217-219).
} 


\section{Conclusion}

This article has addressed the influence aim problem of petitionary prayer (IAP); the problem of whether petitionary prayer aimed at counterfactually influencing God is consistent with the traditional Christian affirmations of divine omniscience, omnipotence, and omnibenevolence. After introducing the IAP and briefly discussing some representative approaches to it, this article suggested that retrieval of the oftneglected cosmic conflict motif that appears in Scripture and the Christian tradition might advance the discussion and briefly articulated a cosmic conflict rules-ofengagement framework as a potentially viable avenue to address the IAP. In brief, there may be rules of engagement in the cosmic conflict, to which God has agreed for morally sufficient reasons, such that God is morally restricted from bringing about some goods unless God is petitioned to bring such goods about. I have argued that this approach is both possible and consistent with divine omniscience, omnibenevolence, omnipotence, and the influence aim of petitionary prayer and, as such, warrants further consideration in contemporary discussions of petitionary prayer. 


\section{References}

Adams, Robert Merrihew. 1972. "Must God Create the Best?" Philosophical Review 81 (3): 317-32.

Arnold, Clinton. 1992. Powers of Darkness: Principalities \& Powers in Paul's Letters. IVP Academic.

Barth, Karl. 2002. Prayer. 50th Anniversary Edition. Westminster John Knox.

Basinger, David. 1983. "Why Petition an Omnipotent, Omniscient, Wholly Good God?" Religious Studies 19: 25-42.

. 2003. "God Does Not Necessarily Respond to Prayer," in Contemporary Debates in Philosophy of Religion, edited by Michael L. Peterson and Raymond J. VanArragon. Blackwell.

Boyd, Gregory A. 1997. God at War: The Bible and Spiritual Conflict. IVP Academic.

Brümmer, Vincent. 2008. What Are We Doing When We Pray? On Prayer and the Nature of Faith. Revised ed. Ashgate.

Cocksworth, Ashley. 2018. Prayer: A Guide for the Perplexed. T\&T Clark.

Cohoe, Caleb Murray. 2014. "God, Causality, and Petitionary Prayer." Faith and Philosophy 31 (1): 24-45.

. 2018. "How Could Prayer Make a Difference?" European Journal for Philosophy of Religion 10 (2): 171-85.

Crisp, Oliver. 2010. Retrieving Doctrine: Essays in Reformed Theology. IVP Academic.

Crump, David. 2006. Knocking on Heaven's Door: A New Testament Theology of Petitionary Prayer. Baker Academic.

Cupit, Geoffrey. 1994. "How Requests (and Promises) Create Obligations." Philosophical Quarterly 44: 439-55.

Davison, Scott A. 2009. "Petitionary Prayer," in The Oxford Handbook of Philosophical Theology, edited by Thomas P. Flint and Michael C. Rea. Oxford University Press.

2017. Petitionary Prayer: A Philosophical Investigation. Oxford University Press.

. 2018. "Requests and Responses: Reply to Cohoe." European Journal for Philosophy of Religion 10 (2): 187-94.

Di Muzio, Gianluca. 2018. "A Collaborative Model of Petitionary Prayer." Religious Studies 54 (1): 37-54. 
DiRoberts, Kyle D. 2019. Prayer, Middle Knowledge, and Divine-Human Interaction. Wipf \& Stock.

Dougherty, Trent and Justin P. McBrayer, eds. 2014. Skeptical Theism: New Essays. Oxford University Press.

Flint, Thomas P. 1998. Divine Providence: The Molinist Account. Cornell University Press.

Franks, W. Paul. 2009. "Why a Believer Could Believe that God Answers Prayers." Sophia 48 (3): 319-324.

Gatumu, Kabiro wa. 2008. The Pauline Concept of Supernatural Powers: A Reading from the African Worldview. Paternoster.

Gregg, Brian Han. 2016. What Does the Bible Say About Suffering? IVP Academic, 2016.

Griffin, David Ray. 2004. God, Power, and Evil: A Process Theodicy. Westminster John Knox.

Hartshorne, Charles. 1984. Omnipotence and Other Theological Mistakes. State University of New York Press.

Heiser, Michael S. 2015. The Unseen Realm: Recovering the Supernatural Worldview of the Bible. Lexham Press.

Hill, Scott. 2018. "Aquinas and Gregory the Great on the Puzzle of Petitionary Prayer." Ergo 5 (15): 407-418.

Howard-Snyder, Daniel and Frances Howard-Snyder. 2010. "The Puzzle of Petitionary Prayer," European Journal for Philosophy of Religion 2 (2): 43-68.

Lewis, C.S. 1952. Mere Christianity. HarperOne, reprited in 2001, first printed 1952.

Longenecker, Richard N., ed. 2001. Into God's Presence: Prayer in the New Testament. Eerdmans.

Murray, Michael J. and Kurt Meyers. 1994. "Ask and It Will Be Given to You." Religious Studies 30 (3): 311-330.

Oord, Thomas Jay. 2015. The Uncontrolling Love of God: An Open and Relational Account of Providence. IVP Academic.

Parker, Ryan M. and Bradley Rettler. 2017. “A Possible-Worlds Solution to the Puzzle of Petitionary Prayer." European Journal for Philosophy of Religion 9 (1): 17986.

Peckham, John C. 2018. Theodicy of Love: Cosmic Conflict and the Problem of Evil. Baker Academic.

Pickup, Martin. 2018. "Answer to our Prayers: The Unsolved But Solvable Problem of 
Petitionary Prayer." Faith and Philosophy 35 (1): 84-104.

Plantinga, Alvin. 1977. God, Freedom, and Evil. Eerdmans.

1974. The Nature of Necessity. Clarendon Press.

Reibsamen, Jonathan. 2019. "Divine Goodness and the Efficacy of Petitionary Prayer." Religious Studies 55 (1): 131-44.

Russell, Jeffrey Burton. 1981. Satan: The Early Christian Tradition. Cornell University Press.

Smith, Nicholas D. and Andrew C. Yip. 2010. "Partnership with God: A Partial Solution to the Problem of Petitionary Prayer." Religious Studies 46 (3): 395-410.

Stump, Eleonore. 1979. "Petitionary Prayer." American Philosophical Quarterly 16 (2): 81-91.

. 2012. Wandering in the Darkness: Narrative and the Problem of Suffering. Oxford University Press.

Suchocki, Marjorie Hewitt. 1996. In God's Presence: Theological Reflections on Prayer. Chalice Press.

Swinburne, Richard. 1998. Providence and the Problem of Evil. Clarendon.

Tiessen, Terrance. 2000. Providence and Prayer: How Does God Work in the World? IVP Academic.

Woznicki, Christopher. 2017. "Is Prayer Redundant? Calvin and the Early Reformers on the Problem of Petitionary Prayer." JETS 60 (2): 333-48.

. 2018. "What Are We Doing When We Pray? Rekindling a Reformation Theology of Petitionary Prayer." Calvin Theological Journal 53: 319-43. 